\title{
ANALISIS TEMBAGA (Cu) DAN TIMBAL (Pb) DALAM AIR LAUT DAN SEDIMEN DI PERAIRAN PANTAI LOLI KECAMATAN BANAWA KABUPATEN DONGGALA
}

\author{
Analysis of Copper (Cu) and Lead (Pb) in Seawater and Sediment in Loli Coastal Waters \\ Subdistrict Banawa District Donggala
}

\author{
*Santi, Vanny M. A. Tiwow, dan Siang Tandi Gonggo \\ Pendidikan Kimia/FKIP - Universitas Tadulako, Palu - Indonesia 94118 \\ Received 20 September 2017, Revised 20 October 2017, Accepted 22 November 2017
}

\begin{abstract}
This study aimed to determine by concentration of heavy $\mathrm{Cu}$ and $\mathrm{Pb}$ in seawater and sedimen in coastal waters Loli subdistrict Banawa, district Donggala. The method used was destruction and using atomic absorption spectrophotometer (AAS) instrument. Samples of seawater and sediment were taken by two sampling points. Samples were destructed by using a solution of $\mathrm{HNO}_{3}$ and $\mathrm{HClO}_{4}$ with ratio 4: 1 . The levels were measured at a wavelength of $325.7 \mathrm{~nm}$ for $\mathrm{Cu}$ and $217 \mathrm{~nm}$ for $\mathrm{Pb}$. The analysis result obtained that the levels of $\mathrm{Pb}$ in the seawater in the range of 0,531-0.671 $\mathrm{mg} / \mathrm{L}$, while for $\mathrm{Cu}$ in the range of 0.009-0.090 $\mathrm{mg} / \mathrm{L}$ it can be concluded that the levels of $\mathrm{Pb}$ and $\mathrm{Cu}$ in sea water has exceeded the levels were of $0,008 \mathrm{mg} / \mathrm{L}$. For sediment samples obtained that Pb levels were around 1,78-7,73 mg/kg while for Cu 15.86-68.88 $\mathrm{mg} / \mathrm{kg}$ so Cu in sediment was up to $30 \mathrm{mg} / \mathrm{kg}$ while the levels of Pb was not exceed the tolerance limits of $33 \mathrm{mg} / \mathrm{kg}$.
\end{abstract}

Keywords: Lead $(\mathrm{Pb})$, copper $(\mathrm{Cu})$, sea water, sediment, atomic absorption spectrophotometer (AAS)

\section{Pendahuluan}

Daerah Loli terletak di Kecamatan Banawa Kabupaten Donggala, Sulawesi Tengah. Daerah ini terbagi atas 5 desa yakni Loli Oge, Loli Saluran, Loli Tasiburi, Loli Pesua dan Loli Dondo, masingmasing di daerah pesisir pantainya banyak terdapat aktivitas yang diakibatkan oleh pertumbuhan penduduk yang semakin meningkat. Perkembangan suatu daerah akan berdampak pada lingkungan sekitarnya, apabila tidak direncanakan dengan baik, maka akibatnya akan terjadi penurunan kualitas perairan akibat dari peningkatan buangan limbah yang membahayakan bagi manusia dan biota perairan dan salah satu bentuk pencemaran akibat buangan industri adalah pencemaran yang ditimbulkan oleh limbah yang mengandung logam (Syahminan, dkk., 2015).Aktivitas yang berlangsung di perairan pantai Loli terbagi atas 4 wilayah.

Wilayah 1 yakni aktivitas pengangkutan kerikil oleh kapal tongkang yang ditarik oleh kapal ke pulau Kalimantan.Wilayah 2 yakni pangkalan bahan bakar minyak Pertamina (marketing operation terminal VII Donggala) yang terdapat di Loli Oge. Bahan bakar ini berasal dari kota Balikpapan melalui jalur laut dengan menggunakan kapal tanker selanjutnya minyak yang datang ditampung dalam wadah penyimpanan.

Wilayah 3 yakni pelabuhan pembongkaran peti kemas yang berasal dari kota Surabaya yang

*Correpondence

Santi

Program Studi Pendidikan Kimia, Fakultas Keguruan dan IImu Pendidikan, Universitas Tadulako

e-mail: santichemistry@gmail.com

Published by Universitas Tadulako 2017 terdapat di desa Loli Pesua, peti kemas tersebut kemudian diangkut dan didistribusikan ke beberapa toko di kota Palu dan berlangsung setiap hari. Di daerah ini juga terdapat dermaga serta sebagian kapal bersandar di sini dan dari aktivitasnya memberikan sumbangan pencemaran di perairan Loli.

Wilayah 4 yakni daerah tambak ikan. Masyarakat yang bermukim dipesisir pantai memanfaatkan laut untuk membuat tambaktambak ikan. Ikan mendapatkan makanan dari sedimen yang diduga telah tercemar logam berat dari berbagai aktivitas yang diuraikan di atas. Hal ini didukung oleh penelitian sebelumnya yang melakukan analisis $\mathrm{Fe}$ dan $\mathrm{Pb}$ di daerah pesisir pelabuhan Taipa diperolah hasil untuk $\mathrm{Fe}$ 0,324 $\mathrm{mg} / \mathrm{L}-0,546 \mathrm{mg} / \mathrm{L}$ dan $\mathrm{Pb} 0,703 \mathrm{mg} / \mathrm{L}-0,919$ mg/L (Ika, dkk., 2012) dan analisis kadar Pb dan Cd di laut dangkal depot pertamina Palu diperoleh hasil untuk $\mathrm{Pb} 14,85 \mu \mathrm{g} / \mathrm{gr}-3,725 \mu \mathrm{g} / \mathrm{gr}$ dan $\mathrm{Pb}$ $0,212 \mu \mathrm{g} / \mathrm{gr}-0,305 \mu \mathrm{g} / \mathrm{gr}$ (Muliati, 2004).

Berdasarkan uraian di atas dapat terlihat perairan pantai Loli merupakan daerah yang sarat dengan aktivitas seperti pelayaran dan perbaikan kapal yang berpotensi memberikan pencemaran seperti pencemaran oleh logam berat.Logam berat merupakan unsur yang tidak dapat dibentuk sendiri oleh tubuh manusia, hewan dan tumbuhtumbuhan sehingga disebut unsur esensial (Durube, dkk., 2007). Logam berat dalam air mudah terserap dan tertimbun dalam fitoplankton yang merupakan titik awal dari rantai makanan, selanjutnya melalui rantai makanan sampai ke organisme lain (Ferdiaz, 1992). Kandungan logam berat dalam air biasanya akan bertambah dari waktu ke waktu karena bersifat bioakumulatif sehingga biota air dapat digunakan sebagai indikator pencemaran logam (Darmono, 1995). 
Logam berat seringkali memasuki rantai makanan di laut dan berpengaruh pada hewan-hewan serta dari waktu ke waktu dapat berpindah-pindah dari sumbernya. Keadaan ini menyebabkan sulit sekali untuk memperkecil pengaruh bahan kimia tersebut terutama apabila pengaruhnya terulang pada tahun-tahun berikutnya dan bilamana logam berat tersebut dilepaskan ke perairan bebas akan terjadi perubahan nilai dari perairan itu baik dari kualitas maupun kuantitas sehingga perairan dapat dianggap tercemar (Arsyad, dkk., 2012).

Sedimen merupakan akumulasi dari mineralmineral dan pecahan-pecahan batuan yang bercampur dengan hancuran cangkang dan tulang dari organisme laut serta partikel lain yang terbentuk lewat proses kimia yang terjadi di laut. Pada umummnya logam-logam berat yang terdekomposisi pada sedimen tidak terlalu berbahaya bagi mahluk hidup perairan, tetapi oleh adanya pengaruh kondisi akuatik yang bersifat dinamis seperti perubahan $\mathrm{pH}$, akan memyebabkan logam-logam terendap dalam sedimen terionisasi ke perairan dan hal inilah yang merupakan bahan pencemar dan akan memberikan sifat toksik terhadap organisme laut bila ada dalam jumlah yang berlebih (Siaka, 2008). Hadirnya logam berat dalam sedimen terutama disebabkan oleh deposisi logam berat dari kolom air yang terikat dalam partikel dan mengendap di dasar perairan sehingga membentuk sedimen. Logam berat dalam sedimen pada perairan terutama berasal dari berbagai aktivitas seperti peremajaan kapal yang memungkinkan terjadinya tumpahan cat, minyak dempul dan pelumas yang mengandung logam berat ke dalam badan air. Partikel dalam badan air berikatan dengan lumpur dan mengendap (Palar, 1994).

Logam di sedimen bisa berada dalam berbagai bentuk dan perikatan antara lain sebagai ion bebas dan berikatan dengan karbonat, logam bentuk ini disebut sebagai logam yang sangat labil sehingga mudah lepas keperairan serta mudah diserap oleh organisme. Perikatan dengan bahan organik serta sulfida juga bisa menghasilkan logam dalam bentuk yang mudah teroksidasi (Yu, dkk., 2010). Logam juga bisa berikatan dengan oksida $\mathrm{Fe} / \mathrm{Mn}$ jika konsentrasinya tinggi dan disebut sebagai bentuk yang tereduksi. Hal ini disebabkan karena logam membentuk senyawa kompleks yang stabil. Beberapa logam tersebut diantaranya adalah logam $\mathrm{Pb}$ dan $\mathrm{Cu}$ (Gao, dkk., 2008).

Tembaga $(\mathrm{Cu})$ dan timbal $(\mathrm{Pb})$ merupakan logam berat dan termasuk elemen mikro yang berbahaya bagi makluk hidup. Logam tersebut juga termasuk salah satu komponen penyusun minyak bumi dan produk olahannya.Logam ini diperkirakan banyak terdapat dalam sedimen laut (Fismawati, 2010). Dari hasil survai yang telah dilakukan diketahui bahwa kondisi di perairan pantai Loli teridentifikasi kondisi perairannya telah berubah seperti di bebarapa wilayah sedimennya berwarna hitam akibat tumpahan minyak pelumas dan sisa bahan bakar. Kegiatan perbaikan kapal yang biasanya diikuti dengan pengecetan kapal dan penggantian minyak pelumas juga memberikan peluang masuknya limbah kegiatan di perairan sekitarnya.

\section{Metode}

\section{Alat dan Bahan}

Alat yang digunakan dalam penelitian ini adalah spektrofotometer serapan atom (PG Instrumen AA500), neraca analitik (ADAM PW254), oven, lumpang dan alu, magnetik stir, batang pengaduk, botol semprot, alat pengambil sedimen, freezer, gelas kimia, pipet tetes, gelas ukur, spatula, corong, labu ukur, erlenmeyer, penangas listrik, botol berwarna gelap, $\mathrm{pH}$ meter, ayakan 63 mesh, cawan porselin, dan sarung tangan steril.

Bahan yang digunakan dalam penelitian ini adalah sampel sedimen, air laut, aquades, $\mathrm{HNO}_{3}$ pekat (Smart Lab), tembaga sulfat anhidrat (Merck), timbal nitrat (Merck), kertas saringWhatman no $42, \mathrm{HClO}_{4}$ pekat $($ Merck), $\mathrm{HCl}$ (Smart Lab.), kertas aluminium foil, tissu.

\section{Prosedur Penelitian}

\section{Pengambilan sampel}

Sampel air laut dan sedimen diambil di perairan pantai Loli Kecamatan Banawa Kabupaten Donggala, Sulawesi Tengah. Pengambilan sampel sedimen dilakukan dengan menggunakan pipa PVC dan diambil pada 2 lokasi secara horizontal selanjutnya sampel sedimen dimasukkan kedalam wadah plastik.Sedangkan pengambilan sampel air laut dilakukan secara horizontal pada masing-masing lokasi yang telah ditentukan menggunakan botol aqua berwarna gelap $600 \mathrm{~mL}$. Masing-masing pengambilan sampel dilakukan sebanyak 2 kali dan sebelum dibawa ke laboratorium untuk dianalisis sampel air laut dan sedimen ditambahkan dengan $\mathrm{HNO}_{3} 65$ $\%$.

\section{Pengayakan sampel sedimen}

Sedimen basah diayak dengan ayakan 63 mesh dengan bantuan air laut yang diambil dari tempat pengambilan sampel. Hal ini dilakukan dengan tujuan agar semua butiran yang lolos dari ayakan mencerminkan ukuran yang sebenarnya di alam. Ukuran $\leq 63$ mesh dipilih karena pada ukuran tersebut lebih banyak mengikat senyawa-senyawa logam.Butiran sedimen yang bercampur dengan air diendapkan selama satu hari. Cairan yang jernih didekantasi dan endapannya dikeringkan dalam ovenpada suhu $60^{\circ} \mathrm{C}$. Sedimen kering kemudian digerus, selanjutnya disimpan di dalam gelas kimia dan ditutup dengan aluminium foil sebelum dianalis lebih lanjut (Sahara, 2009).

\section{Penyiapan sampel}

5 gram sedimen kering ditimbang dan dimasukkan dalam gelas kimia, kemudian ditambahkan $125 \mathrm{~mL}$ campuran $\mathrm{HNO}_{3}$ dan 
$\mathrm{HClO}_{4}(4: 1)$ dan didestruksi selama 3 jam pada suhu $120^{\circ} \mathrm{C}$.Hasil destruksi ini disaring dan filtratnya ditampung dalam labu ukur $250 \mathrm{~mL}$ dan diencerkan sampai tanda batas (Sahara, 2009). Sedangkan untuk sampel air laut sebanyak $100 \mathrm{~mL}$ diambil kemudian disaring menggunakan kertas saring Whatman no. 42. Filtrat hasil penyaringan diambil sebanyak $50 \mathrm{~mL}$ lalu dimasukkan ke dalam gelas kimia dan diasamkan dengan pHnya diatur sampai 5. Kandungan $\mathrm{Pb}$ dan $\mathrm{Cu}$ dalam filtrat untuk sampel air dan sedimen diukur dengan spektrofotometer serapan atom.

\section{Pembuatan deret kerja dan kurva kalibrasi}

Dari larutan standar $\mathrm{Cu}$ dan $\mathrm{Pb} 1000$ ppm dibuat deret kerja sebagai berikut:

Logam $\mathrm{Cu}$ : 0,5 ppm; 1 ppm; 1,5 ppm; 2 ppm dan 2,5 ppm; logam Pb : 1 ppm; 2 ppm; 3 ppm; 4 $\mathrm{ppm}$ dan $5 \mathrm{ppm}$. Deret ini diukur serapannya pada panjang gelombang $217 \mathrm{~nm}$ untuk $\mathrm{Pb}$ dan 324,7 $\mathrm{nm}$ untuk $\mathrm{Cu}$. Kurva kalibrasi dibuat dengan memplot konsentrasi terhadap absorban.

\section{Analisis Data}

Hasil pengukuran yang diperoleh menggunakan alat spektrofotometer serapan atom, konsentrasi $\mathrm{Cu}$ dan $\mathrm{Pb}$ dalam sampel air laut dan sedimen berupa konsentrasi logam dalam larutan sampel (mg/L). Selanjutnya konversi konsentrasi larutan sampel (ppm) menjadi konsentrasi logam berat kering sampel $(\mathrm{mg} / \mathrm{kg})$ dengan menggunakan persamaan berikut (Sahara, 2009): $M=(\mathrm{q} . \mathrm{N}) / \mathrm{p}$, dimana $\mathrm{M}$ adalah kadar $\mathrm{Cu}$ dan $\mathrm{Pb}$ dalam sedimen kering $(\mathrm{mg} / \mathrm{kg})$; $\mathrm{q}$ adalah volume penetapan sampel $(\mathrm{L}) ; \mathrm{N}$ adalah konsentrasi larutan sampel $(\mathrm{mg} / \mathrm{L})$ dan $\mathrm{p}$ adalah berat kering sampel $(\mathrm{kg})$

\section{Hasil Dan Pembahasan}

\section{Tembaga (Cu) pada air laut}

Berdasarkan hasil pengamatan maka diperoleh konsentrasi $\mathrm{Cu}$ pada sampel air laut terlihat pada Tabel 1

Tabel 1. Konsentrasi $\mathrm{Cu}$ pada air laut

\begin{tabular}{cccc}
\hline Sampel & $\begin{array}{c}\text { Kode } \\
\text { sampel }\end{array}$ & absorbansi & konsentrasi sampel \\
\hline Air & I A & 0,005 & 0,090 \\
Laut & I B & 0,004 & 0,020 \\
& II A & 0,004 & 0,020 \\
& II B & 0,002 & 0,009 \\
\hline
\end{tabular}

Keterangan :

I A :Tempat sampel wilayah 1 dan 2 pada pengambilan pertama (dermaga pembongkaran BBM dan pengangkutan kerikil oleh kapal-kapal tongkang) dengan jarak $\pm 10 \mathrm{M}$

I B : Tempat sampel wilayah 3 dan 4pada pengambilan pertama (dermaga pembongkaran peti kemas dan daerah tambak ikan) dengan jarak $\pm 7 \mathrm{M}$
IIA : Tempat sampel wilayah 1 dan 2 pada pengambilan ke dua (dermaga pembongkaran BBM dan pengangkutan kerikil oleh kapal-kapal tongkang) dengan jarak $\pm 10 \mathrm{M}$

II B : Tempat sampel wilayah 3 dan 4 pada pengambilan ke dua ( dermaga pembongkaran peti kemas dan daerah tambak ikan) dengan jarak \pm 7 $\mathrm{M}$

Hasil penelitian menunjukkan bahwa konsentrasi $\mathrm{Cu}$ untuk sampel air laut rata-rata memiliki kandungan yang tinggi di setiap wilayah pengambilan sampel yakni berada pada kisaran $0,009 \mathrm{mg} / \mathrm{L}$ sampai dengan $0,090 \mathrm{mg} / \mathrm{L}$. Hasil yang diperoleh bila dibandingkan dengan NAB air laut untuk $\mathrm{Cu}$ yakni $0,008 \mathrm{mg} / \mathrm{L}$ maka dapat dikatakan bahwa kadar $\mathrm{Cu}$ pada air laut telah melampaui nilai ambang batas yang ditentukan oleh pemerintah.

Tingginya konsentrasi $\mathrm{Cu}$ di wilayah perairan pantai Loli dipengaruhi oleh aktivitas doking kapal di dermaga yang mencakup peremajaan badan kapal berupa penggantian kayu dan pengecetan ulang, dimana logam $\mathrm{Cu}$ merupakan bahan pemberi warna biru dan metalik pada cat anti karat pada kapal yang berguna melapisi dan menjaga ketahanan (Palar, 1994), adanya pengkayaan logam berat tersebut oleh aktivitas antropogenik seperti seringnya penggunaan logam berat dalam bahan baku cat (Sudarso, dkk., 2015), bahan pengawet kayu dan cat anti karat pada lambung kapal, cairan pembersih lantai yang mengandung $\mathrm{CuO}$, dan dari cat pelapis kapal (Agustina, dkk., 2014)

\section{Logam Tembaga (Cu) pada sedimen}

Penentuan konsentrasi $\mathrm{Cu}$ dalam berat sampel sedimen kering $(\mathrm{mg} / \mathrm{kg})$ dikonversi dari konsentrasi logam dalam larutan sampel (mg/L) disajikan pada Tabel 2.

Tabel 2. Data konsentrasi $\mathrm{Cu}$ dalam sedimen berat kering $(\mathrm{mg} / \mathrm{kg})$

\begin{tabular}{cccc}
\hline Sampel & $\begin{array}{c}\text { Kode } \\
\text { sampel } \\
\text { Sampel }\end{array}$ & $\begin{array}{c}\text { konsentrasi } \\
\text { pada } \\
\text { cuplikan } \\
\text { sampel (mg/L) }\end{array}$ & $\begin{array}{c}\text { konsentrasi } \\
\text { berat kering } \\
\text { sampel (mg/kg) }\end{array}$ \\
\hline Sedimen & I A & 0,317 & 15,86 \\
& I B & 1,397 & 69,88 \\
& II A & 0,482 & 24,11 \\
& II B & 1,191 & 59,55 \\
\hline
\end{tabular}

Data Tabel 2 menunjukkan hasil konsentrasi dari sampel sedimen kadar $\mathrm{Cu}$ berada pada kisaran $24,11 \mathrm{mg} / \mathrm{kg}$ sampai dengan $69,88 \mathrm{mg} / \mathrm{kg}$. Jika mengacu pada petunjuk kualitas sedimen konsentrasi maksimum $\mathrm{Cu}$ pada sedimen yang dapat ditolerir oleh organisme adalah sebesar 30 $\mathrm{mg} / \mathrm{kg}$ berat kering sedimen (Febris \& Werner, 1994). Maka dapat terlihat bahwa sampel sedimen yang terdapat pada lokasi I B dengan nilai 69,88 $\mathrm{mg} / \mathrm{kg}$ dan titik II B $59,55 \mathrm{mg} / \mathrm{kg}$ telah melampaui ambang batas.

Adanya perbedaan tekstur tanah pada sedimen merupakan salah satu faktor yang menyebabkan 
konsentrasi $\mathrm{Cu}$ pada masing-masing lokasi berbeda karna pada penelitian ini tekstur tanah pada sedimen di wilayah I B dengan nilai tertinggi $(69,88 \mathrm{mg} / \mathrm{kg})$ merupakan pasir halus sedangkan pada wilayah I A yang memiliki konsentrasi terkecil $(15,86 \mathrm{mg} / \mathrm{kg})$ yang merupakan pasir sangat kasar hal ini dikarenakan logam berat cenderung terserap pada sedimen yang mempunyai diameter yang relatif kecil dan permukaannya halus (Wahab \& Mutmainnah, 2005). Secara alami ukuran butiran dan sumber logam dalam sedimen dipegaruhi oleh dua faktor yakni antropogenik dan masuknya logam secara alami (Sahara, 2009).Pada umumnya kandungan logam berat tertinggi terakumulasi pada partikel sedimen yang lebih kecil dan kandungan logam berat terendah terakumulasi pada partikel yang berukuran yang lebih besar (Siaka, 2008). Arus dan gelombang merupakan faktor utama yang menentukan arah dan sebaran sedimen dimana kekuatan ini menyebabkan karakteristik sedimen berbeda, sehingga pada dasar perairan disusun oleh berbagai kelompok populasi sedimen (Syahminan, dkk., 2015)

Hasil pengamatan juga menunjukkan bahwa kadar $\mathrm{Cu}$ pada sedimen lebih tinggi dibandingkan dengan air laut hal ini menunjukkan adanya akumulasi $\mathrm{Cu}$ dalam sedimen. Rendahnya kadar logam berat pada air laut, bukan berarti bahan cemaran yang mengandung logam berat tersebut tidak berdampak negatif pada perairan tetapi lebih disebabkan oleh kemampuan perairan tersebut untuk mengencerkan bahan cemaran yang cukup tinggi. Kecepatan sedimentasi yang tinggi menyebabkan penyebaran logam berat menyebar ke seluruh dasar perairan dan dibantu dengan pola pergerakan arus yang terjadi selama dua kali dalam sehari. Pergerakan logam sangat dipengaruhi oleh bentuk dan tipe perikatan logam serta ketersediannya dalam lingkungan perairan (Syahminan, dkk., 2015). Selain itu, jika di liat dari nilai $\mathrm{Ksp} \mathrm{Cu}(\mathrm{OH})_{2}$ diperairan pantai Loli berkisar antara $2 \times 10^{-8} \mathrm{~s} / \mathrm{d} 2 \times 10^{-6,2}$ sedangkan tetapan hasil kali kelarutan $\mathrm{Cu}(\mathrm{OH})_{2}$ sebesar $2 \times$ $10^{-19}$. Hal tersebut mengidentifikasikan bahwa $\mathrm{Cu}$ diperairan akan lebih banyak mengendap.Hal ini juga dipengaruhi oleh kenaikan $\mathrm{pH}$ pada badan perairan biasanya akan diikuti dengan semakin kecilnya kelarutan dari senyawa-senyawa logam dapat terlihat dari $\mathrm{pH}$ perairan Loli yaitu 7,1 sampai dengan 8,5 .

Perubahan tingkat stabil dari persenyawaan seperti hidroksida, oksida, karbonat dan sulfida biasanya terlihat dalam bentuk pergeseran. Umumnya pada $\mathrm{pH}$ yang tinggi maka kestabilan bergeser dari karbonat kehidroksida.Hidroksidahidroksida ini mudah sekali membentuk ikatan permukaan dengan partikel yang terdapat pada badan perairan dan lama-kelamaan persenyawaan yang terjadi antara partikel dengan senyawa hidroksida yang ada pada badan perairan akanmengendap dan membentuk sedimen. Pengendapan partikulat khususnya partikel bioorganik memegang peranan penting dalam pengikatan logam berat dan siklus partikulat yang ada dalam laut akan terkendalikan oleh froduktivitas primer dari plankton (Ali \& Rina, 2013).

\section{Timbal (Pb) pada air laut}

Berdasarkan hasil pengamatan maka diperoleh konsentrasi $\mathrm{Pb}$ pada sampel air laut di sajikan pada Tabel 3.

Tabel 3. Konsentrasi $\mathrm{Pb}$ pada air laut

\begin{tabular}{cccc}
\hline Sampel & $\begin{array}{c}\text { Kode } \\
\text { sampel }\end{array}$ & absorbansi & konsentrasi sampel \\
\hline
\end{tabular}

$\begin{array}{crrr}\text { Air } & \text { I A } & 0,007 & 0,587 \\ \text { Laut } & \text { I B } & 0,008 & 0,671 \\ & \text { II A } & 0,007 & 0,587 \\ & \text { II B } & 0,006 & 0,531\end{array}$

Hasil penelitian menunjukkan bahwa konsentrasi $\mathrm{Pb}$ untuk sampel air laut rata-rata memiliki kandungan yang tinggi di setiap wilayah pengambilan sampel yakni berada pada kisaran $0,531 \mathrm{mg} / \mathrm{L}$ sampai dengan $0,671 \mathrm{mg} / \mathrm{L}$. Hasil yang diperoleh bila dibandingkan dengan NAB air laut yang dapat ditolerir yakni $0,008 \mathrm{mg} / \mathrm{L}$ maka dapat dikatakan bahwa kadar $\mathrm{Pb}$ pada air laut telah melampaui nilai ambang batas yang ditentukan oleh pemerintah. Adanya peningkatan konsentrasi logam dalam badan air diperkirakan terkait dengan aktivitas pelayaran dan doking kapal yang menggunakan bahan bakar minyak, pelumas dan sisa-sisa dari pengerjaan doking kapal tercecer dan langsung masuk ke badan air sehingga memberikan peluang terhadapat peningkatan konsentrasi logam berat dalam badan perairan. Tingginya konsetrasi $\mathrm{Pb}$ dalam lingkungan perairan dapat disebabkan oleh berbagai faktor yakni aktivitas manusia seperti aktivitas perbengkelan, pembuangan limbah rumah tangga yang mengandung timbal, pengikisan batuan mineral serta tingginya pemakaian bensin berbahan bakar timbal (Ika, dkk., 2012).

\section{Timbal (Pb) pada sedimen}

Konsentrasi $\mathrm{Pb}$ dalam berat sampel sedimen kering $(\mathrm{mg} / \mathrm{kg})$ dikonversi dari konsentrasi logam dalam larutan sampel $(\mathrm{mg} / \mathrm{L})$ disajikan pada Tabel 4.

Kandungan sampel sedimen seperti terlihat pada Tabel 4 yang memiliki kandungan terbanyak yakni pada kode sampel II B yaitu $7,73 \mathrm{mg} / \mathrm{kg}$. Jika mengacu pada petunjuk kualitas sedimen untuk $\mathrm{Pb}$ yaitu $33 \mathrm{mg} / \mathrm{kg}$ maka dapat dikatakan bahwa kandungan $\mathrm{Pb}$ pada sedimen belum melampaui nilai ambang batas atau masih dalam batas toleransi (Febris \& Werner, 1994). Berdasarkan hasil pengukuran kadar $\mathrm{Pb}$ dalam sedimen dapat dikatakan meskipun telah terkontaminasi namun belum termaksud dalam katagori berat. Akan tetapi, kontaminasi ini seiring berjalanya waktu akan menimbulkan akumulasi 
baik pada tubuh biota yang hidup dan mencari makan di dalam maupun di luar sedimen atau dasar perairan akan berbahaya bagi biota perairan yang pada gilirannya akan berbahaya pula bagi manusia yang mengkonsumsi biota tersebut (Ahmad, 2009).

Tabel 4. Data Konsentrasi Pb dalam sedimen berat kering $(\mathrm{mg} / \mathrm{kg})$

\begin{tabular}{cccc}
\hline Sampel & $\begin{array}{c}\text { Kode } \\
\text { sampel } \\
\text { Sampel }\end{array}$ & $\begin{array}{c}\text { konsentrasi } \\
\text { pada } \\
\text { cuplikan } \\
\text { sampel (mg/L) }\end{array}$ & $\begin{array}{c}\text { konsentrasi } \\
\text { berat kering } \\
\text { sampel (mg/kg) }\end{array}$ \\
\hline Sedimen & I A & 0,035 & 1,78 \\
& I B & 0,315 & 6,98 \\
& II A & 0,312 & 6,61 \\
& II B & 0,154 & 7,73 \\
\hline
\end{tabular}

Timbal $(\mathrm{Pb})$ merupakan logam berat yang sangat beracun dan tidak dibutuhkan oleh manusia, sehingga bila makanan tercemar oleh logam tersebut maka tubuh akan mengeluarkannya (Hardiani, dkk., 2011). Dalam tubuh manusia logam $\mathrm{Pb}$ dapat menghambat aktivitas enzim yang terlibat dalam pembentukan hemoglobin $(\mathrm{Hb})$ dan sebagian kecil terakumulasi dalam ginjal, hati, jaringan lemak dan rambut (Widyowati, dkk., 2008).

Berdasarkan data di atas terlihat bahwa terdapat perbedaan hasil yang diperoleh untuk air laut lebih tinggi dibandingkan dengan sedimen dimana yang seharusnya kandungan logam berat pada sedimen lebih tinggi dibandingkan dengan badan perairan karena logam akan mengendap pada sedimen. hal ini mungkin disebabkan karena proses akumulasi logam tersebut belum lama berlangsung. Jika dilihat dari nilai Jika di lihat dari nilai Ksp $\mathrm{Pb}(\mathrm{OH})_{2}$ diperairan pantai Loli yakni berkisar antara $3 \times 10^{-5} \mathrm{~s} / \mathrm{d} 3 \times 10^{-3,2}$ sedangkan tetapan hasil kali kelarutan $\mathrm{Pb}(\mathrm{OH})_{2}$ sebesar $3 \times 10^{-16}$ bila dibandingkan dengan $\mathrm{Ksp} \mathrm{Cu}(\mathrm{OH})_{2}$ yakni $2 \times 10^{-}$ 19 maka kelarutan dari $\mathrm{Pb}(\mathrm{OH})_{2}$ lebih besar dibandingkan dengan $\mathrm{Cu}(\mathrm{OH})_{2}$ sehingga $\mathrm{Cu}$ lebih banyak terdapat di sedimen dibandingkan dengan $\mathrm{Pb}$. Kelarutan suatu zat bukan sifat mutlak tetapi relatif yaitu berdasarkan besar kecilnya Ksp zat yang bersangkutan (Harjadi, 1989)

\section{Kesimpulan}

Konsentrasi $\mathrm{Pb}$ dan $\mathrm{Cu}$ di wilayah perairan pantai Loli Kecamatan Banawa Kabupaten Donggalawilayah (I A dan II A) pada lokasi dermaga pembongkaran BBM, dermaga pengangkutan kerikil oleh kapal tongkang serta wilayah (I B dan II B) dermaga pembongkaran peti kemas dan daerah tambak ikan yakni untuk $\mathrm{Pb}$ yaitu $0,531-0,671 \mathrm{mg} / \mathrm{L}$. dan untuk $\mathrm{Cu}$ yaitu 0,009-0,090 mg/L. Dari hasil ini dapat disimpulkan bahwa kandungan logam $\mathrm{Pb}$ dan $\mathrm{Cu}$ telah melebihi batas normal yang telah ditentukan oleh pemerintah yaitu $0,008 \mathrm{mg} / \mathrm{L}$. Sedangkan konsentrasi $\mathrm{Pb}$ dan $\mathrm{Cu}$ untuk sedimen kadar logam $\mathrm{Pb}$ yaitu $1,78-7,73 \mathrm{mg} / \mathrm{kg}$ dan $\mathrm{Cu}$ yaitu $15,86-$ $69,88 \mathrm{mg} / \mathrm{kg}$. Untuk sampel sedimen logam $\mathrm{Cu}$ sudah melebihi batas normal yakni $30 \mathrm{mg} / \mathrm{kg}$ sedangkan $\mathrm{Pb}$ belum melebihi batas normal yakni $33 \mathrm{mg} / \mathrm{kg}$

\section{Ucapan Terima Kasih}

Penulis mengucapakan terima kasih kepada Kepala laboratorium Agroteknologi Pertanian Universitas Tadulako dan semua pihak yang telah membantu dalam pelaksanaan penelitian ini.

\section{Referensi}

Agustina, A., Sahara, E. \& Dewi, I. A. K. S. P. (2014). Spesiasi dan bioavailabilitas logam $\mathrm{Cu}$ dan $\mathrm{Zn}$ dalam sedimen dipelabuhan benoa yang diayak basah dan kering. Jurnal Kimia, 8(1), 9-16.

Ahmad, F. (2009). Tingkat pencemaran logam berat dalam air laut dan sedimen di perairan pantai Muna, Kabaena, dan Buton Sulawesi Tenggara. Makara Sains, 13(2), 117-124.

Ali, M. \& Rina. (2013). Kemampuan tanaman mangrove untuk menyerap logam berat mercuri $(\mathrm{Hg})$ dan timbal $(\mathrm{Pb})$. Ilmiah Teknik Lingkungan, 2(2), 29-36.

Arsyad, M., Said, I. \& Suherman. (2012). Akumulasi logam timbal $(\mathrm{Pb})$ dalam ikan balanak (liza melinoptera) yang hidup di perairan muara Poboya. Jurnal Akademika Kimia, 1(4), 181-186.

Darmono. (1995). Logam dalam sistem mabluk hidup. Jakarta: UI Press.

Durube, O. J., Oguwuegbu, C. O. M. \& Egwurugu, N. J. (2007). Heavy metal pollution and human biotoxic effects. International Journal of Physical Sciences, 2(5), 112-118.

Febris, J. G. \& Werner, F. G. (1994). Characterization of toxicants in sedimen from Port Philip Bay. Metal departemen of conservation and metal resourcers Melbourne, Australia.

Ferdiaz, S. (1992). Polusi air dan udara. Yokyakarta: Kanisus. 
Fismawati. (2010). Analisis logam berat krom (Cr) dan timbal $(\mathrm{Pb})$ dalam sedimen muara sungai Palu.Skripsi, Palu: Universitas Tadulako.

Gao, S. X., Chen \& A., L. (2008). Chemical speciation of 12 metal in surface sediments from the northern South China sea under natural grain size. Marine Pollution Bulletin, 56(4), 786-792.

Hardiani, H., Ardiansyah, T. \& Sugesti, S. (2011). Blok mediasi logam timbal $(\mathrm{Pb})$ dalam tanah terkontaminasi limbah sludge industri kertas proses deinking. Jurnal Selulosa, 1(1), 31-41.

Harjadi, W. (1989). Ilmu kimia analitik dasar. Jakarta: Gramedia.

Ika, Tahril \& Said, I. (2012). Analisis kandungan logam timbal $(\mathrm{Pb})$ dan besi $(\mathrm{Fe})$ dalam air laut diwilayag pesisir pelabuhan ferry Taipa Kecamatan Palu Utara. Jurnal Akademika Kimia, 1(4), 181-186.

Muliati. (2004). Ekstraksi logam berat tembaga (Pb) dan cadmium $(C d)$ dalam sedimen laut dangkal depot Pertamina Palu. Skripsi, Palu: Universitas Tadulako.

Palar, H. (1994). Pencemaran dan toksiologi logam berat. Jakarta: Rieneka Cipta.

Sahara, E. (2009). Distribusi logam $\mathrm{Pb}$ dan $\mathrm{Cu}$ pada berbagai ukuran partikel sedimen di pelabuhan Benoa. Jurnal Kimia, 3(2), 75-80.
Siaka, M. L. (2008). Korelasi antara kedalam sedimen dipelabuhan Benoa dan konsentrasi logam berat $\mathrm{Pb}$ dan $\mathrm{Cu}$. Jurnal Kimia, 2(2), 61-70.

Sudarso, Y., Yoga, G. P. \& Suryono, T. (2015). Kontaminasi logam berat dalam di sedimen:Studi kasus pada waduk siguling, Jawa Barat. Manusia dan Lingkungan, 12(1), $28-48$.

Syahminan, Riani, W., Anwar, S. \& Rifardi. (2015). Telaah logam berat $\mathrm{Pb}$ dan $\mathrm{Cd}$ pada sedimen di perairan barat laut dumai Riau. Pengelolaan Sumber Daya Alam dan Lingkungan, 5(2), 133-140.

Wahab, W. A. \& Mutmainnah. (2005). Analisis kandungan logam berat $\mathrm{Pb}$ dan $\mathrm{Zn}$ disekitar perairan pelabuhan Pare-Pare dengan metode adisi standar. Marina Chimika Akta, 6(2), 2124.

Widyowati, W., Sastiono, A. \& Jusuf, R. (2008). Efek toksis logam berat pencegahan dan penanggulangan pencemaran. Yogyakarta: ANDI.

Yu, X., Yana, Y. \& Wang, W. (2010). The distribution of trace metal in surface sediments from the pearl river estuary and the day bay, Southern China. Marine Pollution Bulletin, 60(8), 1364-1370. 